\title{
Temperature conditions at the mountain study site of Bílý Kříž (the Beskids Mts.) during the past 20 years
}

\author{
* Irena Marková', Dalibor Janouš ${ }^{1,2}$, Ondřej Nezval $^{1,2}$ \\ ${ }^{1}$ Centre MendelGlobe - Global climate change and managed ecosystems, Faculty of Forestry and Wood Technology, \\ Mendel University in Brno, Zemédèlská 3, Brno CZ-613 00, Czech Republic, markova@mendelu.cz \\ ${ }^{2}$ Global Change Research Institute - Czech Globe, Czech Academy of Sciences, v. v. i., Bëlidla 4a, Brno CZ-603 00, \\ Czech Republic
}

Abstract: Marková I., Janouš D., Nezval O. 2017: Temperature conditions at the mountain study site of Bílý Kř́ž(the Beskids Mts.) during the past 20 years - Beskydy, 10 (1, 2): 113-122

Global climate change (including temperature changes) had already observable effects on the environment and humanity. Air temperature characteristics have been observed at the mountain study site of Bílý Kř́žz (the Beskids Mts., Czech Republic) since 1989. This paper presents an analysis of long-term (1997-2016) air temperature conditions at this study. Comparison is made of selected long-term mean air temperature characteristics with mean air temperature characteristics for the period 1997-2016. The results show slightly increasing air temperature, as indicated not only by values for mean annual air temperature but also by changes in number of extreme days (summer, tropical, ice, etc.) and occurrence of hot period. Moreover, the length of the growth season has increase slightly.

Keywords: annual air temperature, minimum and maximum air temperature, hot periods, ice and freezing days, summer and tropical days, growth season

\section{Introduction}

The world has been getting warmer since the beginning of the industrial revolution. Overall, the global annual temperature has increased at an average rate of $0.07^{\circ} \mathrm{C}$ per decade since 1880 and an average rate of $0.17^{\circ} \mathrm{C}$ per decade since 1970 according to the Annual Global Analysis for 2016 from NOAA's National Centers for Environmental Information. Although climatologists agree that the climate is warming, the change in the occurrence of extreme meteorological events is still poorly understood. That is because an investigation of such events requires long climatic series (Guiot 2012).

Air temperature fluctuates locally and in short periods due to predictable cyclical events (night - day, summer - winter). Air temperature at a specific site mainly depends on how much energy that site receives from the Sun and how much it emitts back into space. The amount of energy emitted by the site depends significantly on chemical composition of the atmosphere (particularly on the amount of greenhouse gases) (Preining 1992, Ramanathan and Feng 2009, Dang and Unger 2015).

Global climate change (including temperature changes) already has observable effects on the environment and humanity. The ranges of some plants and animals have shifted, trees are often flowering sooner, more intense and longer heat waves are occuring, etc. (Rustad 2008, Jeganathan et al. 2014, Croitoru et al. 2016, Kulakowski et al. 2017, Wason et al. 2017, Vitasse et al. 2018). 
Global climate change also has increased pressure on forest ecosystems. Forest stands are particularly sensitive to climate change, because the long lifetime of trees does not allow for rapid adaptation to environmental changes (Bonan 2008, Linder et al. 2010, D'Amato et al. 2011, Nelson et al. 2016, Altman et al. 2017). Rising temperature and increasing drought will probably be the major constraints on forest trees growth (Crabbe et al. 2016, Mildrexler et al. 2016, Franke et al. 2017, Gustafson et al. 2017, Madrigal-González et al. 2017).

This paper presents an analysis of long-term (1997-2016) air temperature conditions at the mountain study site of Bílý Kříž (the Beskids Mts., Czech Republic).

\section{Material and Methods}

Air temperature characteristics have been observed at the mountain study site of Bílý Kříž (the Beskids Mts., Czech Republic) since 1989. Geographic coordinates of the study site are $49^{\circ} 30^{\prime} \mathrm{N}$ and $18^{\circ} 32^{\prime} \mathrm{E}$ and altitude is $890 \mathrm{~m}$ a.s.l.. The climatological station is a part of the experimental ecological study site of Bílý Kř́ž (Marková et al. 2009) which includes also a spruce stand.

The observer recorded daily air temperature at 07:00, 14:00 and 21:00 and daily minimum and maximum air temperature during 1989-1996. Mercury thermometers placed within a classical meteorological box in an open place were used for the measurements.

Air temperature measurements have been automatized since 1997. A resistance sensor (Pt1000) placed within a classical meteorological box in an open place has been used for the measurements since that time. Air temperature values are recorded at 30-s intervals, and 10-min mean values of these records are automatically stored into a data-logger.

Mean daily air temperature values were calculated for the period 1989-2016 according to the equation:

$$
\mathrm{AT}=(\mathrm{AT} 7+\mathrm{AT} 14+2 * \mathrm{AT} 21) / 4
$$

where AT - daily air temperature $\left({ }^{\circ} \mathrm{C}\right), \mathrm{AT} 7$ - air temperature at 7:00 $\left({ }^{\circ} \mathrm{C}\right)$, AT14 - air temperature at 14:00 $\left({ }^{\circ} \mathrm{C}\right)$, AT2 1 - air temperature at 21:00 $\left({ }^{\circ} \mathrm{C}\right)$.

More detailed analysis of temperature conditions was done for the 20-year period 19972016. Mean annual air temperature, mean daily air temperature, length of the growth season, hot periods and number of temperature extremes (ice, freezing, summer and tropical days and tropical nights) were evaluated for this period.

Therms describing temperature conditions are defined as follows:

- length of the growth season - growth season is obviously defined as a five consecutive days with mean daily air temperature above $5{ }^{\circ} \mathrm{C}$ for the beginning of the growth season and below $5^{\circ} \mathrm{C}$ for the end of the growth season (Chen et al. 2000, Groot and Saucie 2008, Wu et al. 2012),

- hot wave - daily maximum air temperature of more than five consecutive days exceeds the mean maximum air temperature by $5{ }^{\circ} \mathrm{C}$ then the daily maximum air temperature is determined for the place on the basis of values obtained from the normal 30-years period (according to the World Meteorological Organization),

- hot period - the period when daily maximum air temperature of more than five consecutive days exceeds the mean maximum air temperature by $5{ }^{\circ} \mathrm{C}$ then the daily maximum air temperature is determined for this study site on the basis of values obtained from the period of 1989-2016,

- ice day - air temperature for the whole day is below $0{ }^{\circ} \mathrm{C}$,

- freezing day - daily minimum air temperature is below $0{ }^{\circ} \mathrm{C}$,

- summer day - daily maximum temperature is above $25^{\circ} \mathrm{C}$,

- tropical day - daily maximum temperature is above $30^{\circ} \mathrm{C}$,

- super-tropical day - daily maximum temperature is above $35^{\circ} \mathrm{C}$,

- tropical night - daily minimum air temperature is above $20^{\circ} \mathrm{C}$,

The air temperature data obtained were statistically evaluated (using F- and t-tests, regression analysis, and descriptive statistics). 


\section{Results and Discussion}

Mean annual air temperature was $6.3 \pm 0.9^{\circ} \mathrm{C}$ at the study site of Bílý Křŕž during 1997-2016 (Fig. 1). Mean annualair temperature is $5.5 \pm 0.5^{\circ} \mathrm{C}$ for the region of the study site, as determined by extrapolation of data from nearby meteorological stations for the period 1961-2000 presented by Tolasz et al. (2007). Mean annual air temperature was higher in 1997-2016 by about $0.3{ }^{\circ} \mathrm{C}$ compared to that determined by Tolasz et al. (2007). This is consistent with the conclusion of Czech Hydrometeorological Institute that the global average air temperature has increased by 0.1 to $0.2^{\circ}$ in ten years (http://www.infomet.cz/ index.php?id=read \& idd=1490087088).

Mean maximum air temperature was $31.9 \pm$ $2.1^{\circ} \mathrm{C}$ and mean minimum air temperature was $(-17.2) \pm 3.5^{\circ} \mathrm{C}$ at the study site in $1997-2016$ (Fig. 1). The highest maximum air temperature was observed in $2006\left(37.4^{\circ} \mathrm{C}\right.$, a super-tropical day) and the lowest minimum temperature was determined in that same year $\left(-26.1^{\circ} \mathrm{C}\right)$.

Statistical evaluation (with significance level $\alpha=0.05$ ) showed some differences in daily air temperature values at the study site of Bílý Kříž between individual years in the period 19972016 (Tab. 1). The results show that in the past decade daily air temperature was mostly significantly higher in comparison to earlier periods.

\section{Warm period (April-September)}

Warm period is a climatological term, but the warm period is almost identical to growth season for plants. Growth season varies, however, depending on latitude and altitude. It is important to analyse temperature conditions during the warm period, because these conditions during this period affect the development and growth of plants inasmuch as many growth processes (e.g. transpiration, respiration, onset and duration of phenology phases) are influenced by air temperature (Granier et al. 2000, Misson et al. 2002, Carrara et al. 2004, Schleip et al. 2009, Vitasse et al. 2009, Hadden and Grelle 2016, Mekkonen et al. 2017).

Different temperature conditions in individual years influence length of the growth season for plants. Mean length of the growth season was $195 \pm 16$ days at the study site of Bílý Kř́ž during 1997-2016 (Fig. 2). Mean date for the beginning of the growth season was 19 April and mean date for the end of the growth season was 24 October during the period 1997-2016.

Global warming is characterized by more frequent extremity of temperature conditions as seen in hot waves, higher number of tropical days and nights, and the rather newly used term super-tropical days (Guiot 2012, Elizbarashvili et al. 2017, Matcharashvili et al. 2017). The mean number of summer days was 29 at the study site of Bílý Křŕž in the period 1997-2016 (Fig. 3A). A rising number of summer days have been observed from 1997 to the present, but this trend is not yet statistically significant. The mean number of tropical days was 6 and that of tropical nights 0.7 at the study site of Bílý Kř́ž in the period 1997-2016 (Fig. 3B). Even supertropical days were recorded at the study site (in 2006). A slightly rising number of tropical days have been observed from 1997 to the present,

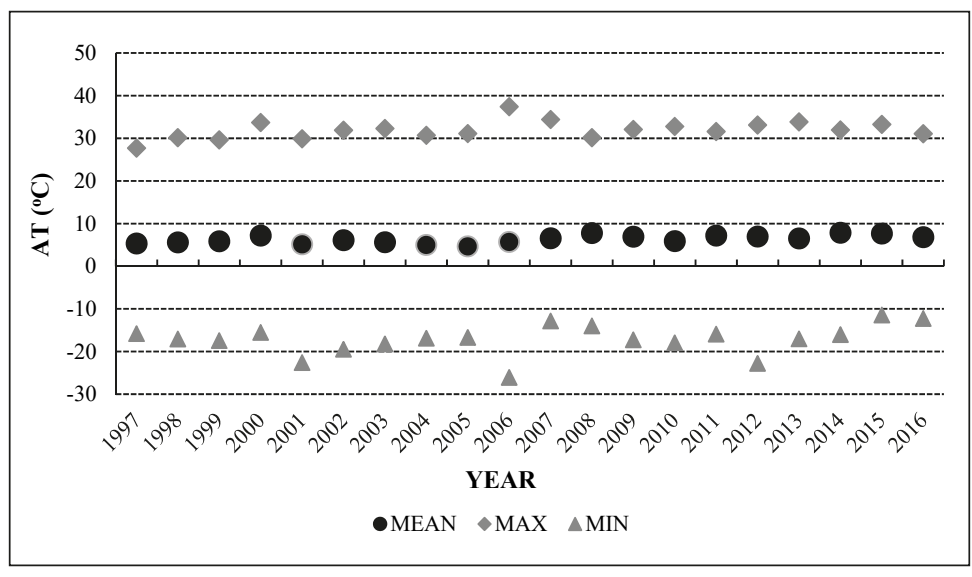

Fig. 1: Mean, minimum and maximum annual air temperature at the study site of Bíly Krí̌̌ (the Beskids Mts.) in the period 1997-2016. 
Tab.1: Statistical differences (significance level $\alpha=0.05$ ) in daily air temperature values at the study site of Bily Křiz (the Beskids Mts.) between individual years in the period 1997-2016.

\begin{tabular}{|c|c|c|c|c|c|c|c|c|c|c|c|c|c|c|c|c|c|c|c|c|}
\hline & $\stackrel{\hat{\sigma}}{\sigma}$ & $\stackrel{\infty}{\stackrel{一}{-}}$ & $\stackrel{\circ}{\circ}$ & 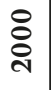 & 융 & ণั & 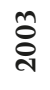 & ষ্ণ & ڤ̊) & ঃั & ¿̊̊ & $\begin{array}{l}\infty \\
\stackrel{\circ}{\circ}\end{array}$ & 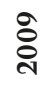 & $\stackrel{\circ}{\stackrel{ }{\circ}}$ & 궁 & 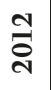 & $\frac{n}{\stackrel{d}{c}}$ & $\underset{d}{\stackrel{্}{~}}$ & $\frac{\operatorname{Ln}}{\stackrel{\text { d }}{~}}$ & 융 \\
\hline 1997 & $\bullet$ & & & & & & & & & & & & & & & & & & & \\
\hline 1998 & & $\bullet$ & & & & & & & & & & & & & & & & & & \\
\hline 1999 & & & - & & & & & & & & & & & & & & & & & \\
\hline 2000 & & & & $\bullet$ & & & & & & & & & & & & & & & & \\
\hline 2001 & & & & & $\bullet$ & & & & & & & & & & & & & & & \\
\hline 2002 & & & & & & $\bullet$ & & & & & & & & & & & & & & \\
\hline 2003 & & & & & & & $\bullet$ & & & & & & & & & & & & & \\
\hline 2004 & & & & & & & & $\bullet$ & & & & & & & & & & & & \\
\hline 2005 & & & & & & & & & $\bullet$ & & & & & & & & & & & \\
\hline 2006 & & & & & & & & & & $\bullet$ & & & & & & & & & & \\
\hline 2007 & & & & & & & & & & & $\bullet$ & & & & & & & & & \\
\hline 2008 & & & & & & & & & & & & $\bullet$ & & & & & & & & \\
\hline 2009 & & & & & & & & & & & & & $\bullet$ & & & & & & & \\
\hline 2010 & & & & & & & & & & & & & & $\bullet$ & & & & & & \\
\hline 2011 & & & & & & & & & & & & & & & $\bullet$ & & & & & \\
\hline 2012 & & & & & & & & & & & & & & & & $\bullet$ & & & & \\
\hline 2013 & & & & & & & & & & & & & & & & & $\bullet$ & & & \\
\hline 2014 & & & & & & & & & & & & & & & & & & $\bullet$ & & \\
\hline 2015 & & & & & & & & & & & & & & & & & & & $\bullet$ & \\
\hline 2016 & & & & & & & & & & & & & & & & & & & & • \\
\hline
\end{tabular}

Black cells - the year in the column was warmer compared to the year in the row, grey cells - the year in the column was cooler compared to the year in the row.

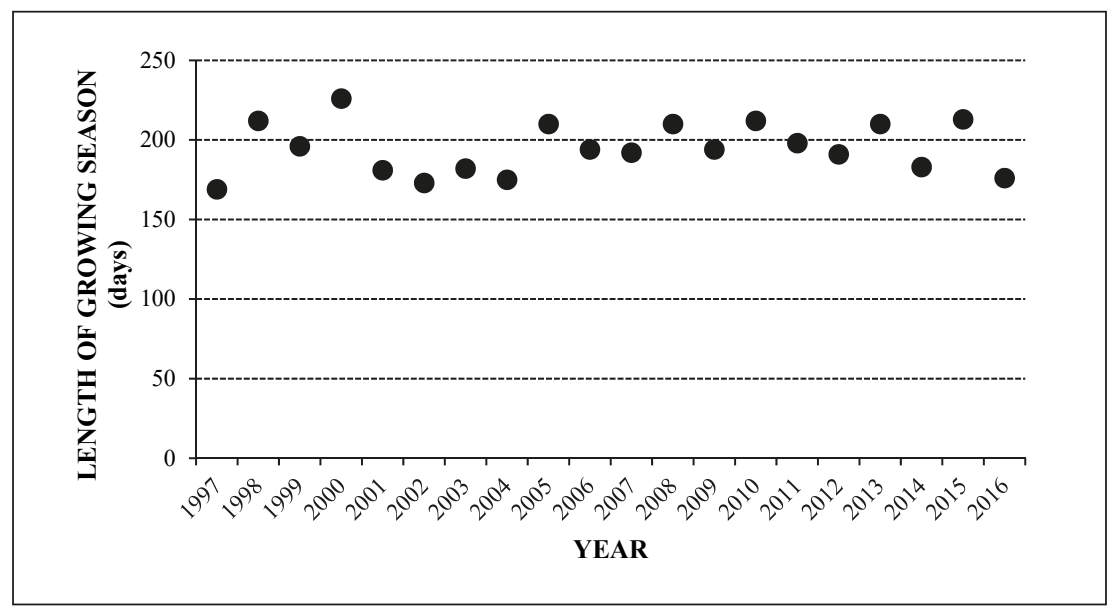

Fig. 2: Length of the growth season at the study site of Bílý Kř́̌̌ (the Beskids Mts.) during 1997-2016 
but this trend, too, is not yet statistically significant. Tropical nights have been recorded more frequently at the study site over the past decade.

Heat waves constitute one of the most significant climatic stressors for the environment and humanity. There are available neither measurements of air temperature for the 1961-1990 normal period nor for the newly established 19812010 normal period. Use of the new 1981-2010 normal period is recommended in the Abridged final report with resolutions (WMO No. 1157) (http://www.wmo.int/aemp/sites/default/files/ wmo_1157_en.pdf). So only "hot period" was evaluated at the study site of Bílý Kříž for the period 1997-2016. Since 1997, the number and length of "hot periods" has been increasing (Fig. 4). "Hot periods" occurred mainly during summer months (June-August). Increasing occurrence of "hot waves" has been reported by other authors (Croitoru et al. 2016, Zampieri et al. 2016, Guerrero-Meseguer et al. 2017).

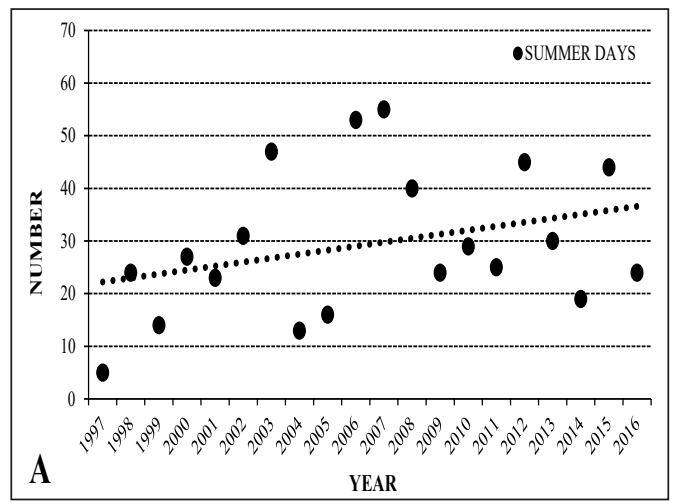

\section{Cold period (October-March)}

Cold period also is a climatological term. Cold period is almost the same as is the dormancy period for plants. Thus, this period is not so important in terms of plant development. An analysis of the air temperature conditions in this period can nevertheless show changes in the temperature conditions over the long-term and which can ultimately affect plant growth and health condition.

Global warming is characterized by more frequent extremity of temperature conditions not only in the warm period but also in the cold period (Matcharashvili et al. 2017). The annual mean number of ice days was 59 and mean number of freezing days was 128 at the study site of Bílý Kříž during 1997-2016 (Fig. 5). A decreasing number of ice and freezing days has been observed from 1997 to the present. This trend was statistically significant (correlation coefficient -0.49).

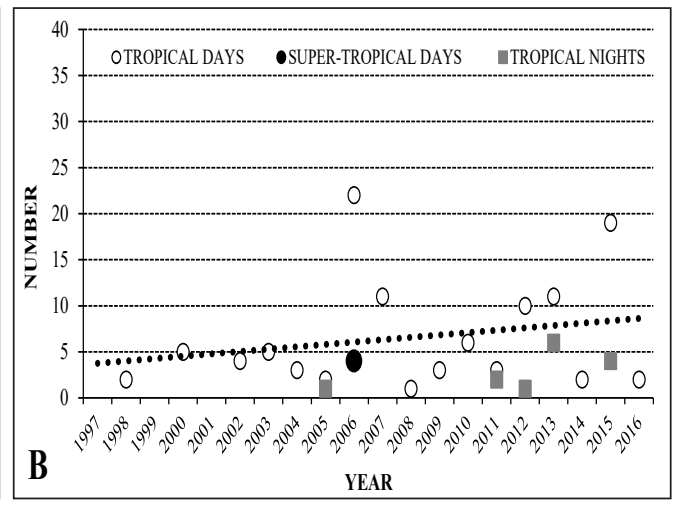

Fig. 3: Number and trend of the number of the summer days (A) and number and trend of the number of tropical days, number of super-tropical days and number of tropical nights (B) at the study site of Bíly Kríz (the Beskids Mts.) in 1997-2016.

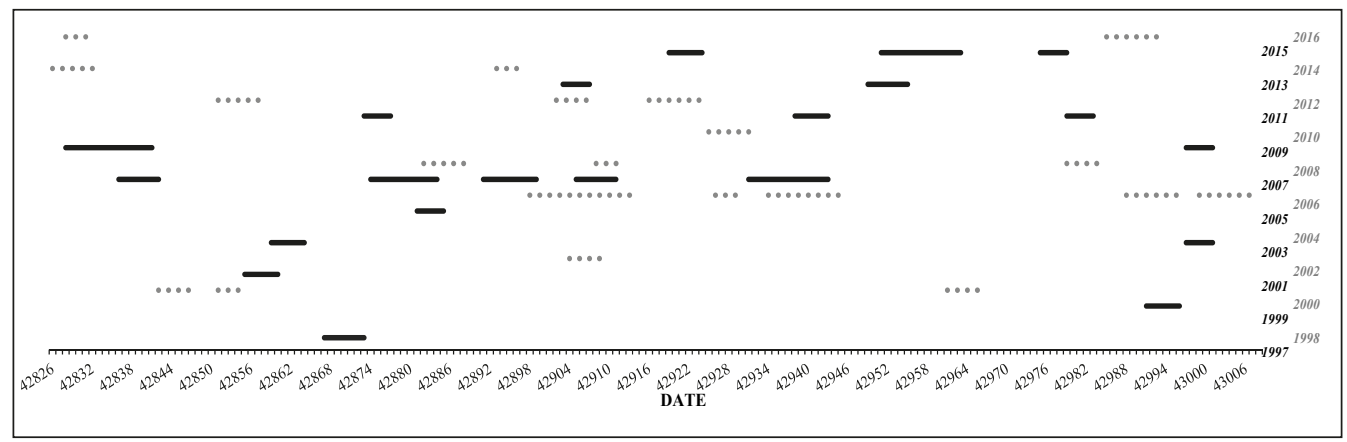

Fig. 4: The occurrence of the "hot periods" at the study site of Bíly Kř́ž (the Beskids Mts.) in the warm period (April-September) during 1997-2016. 


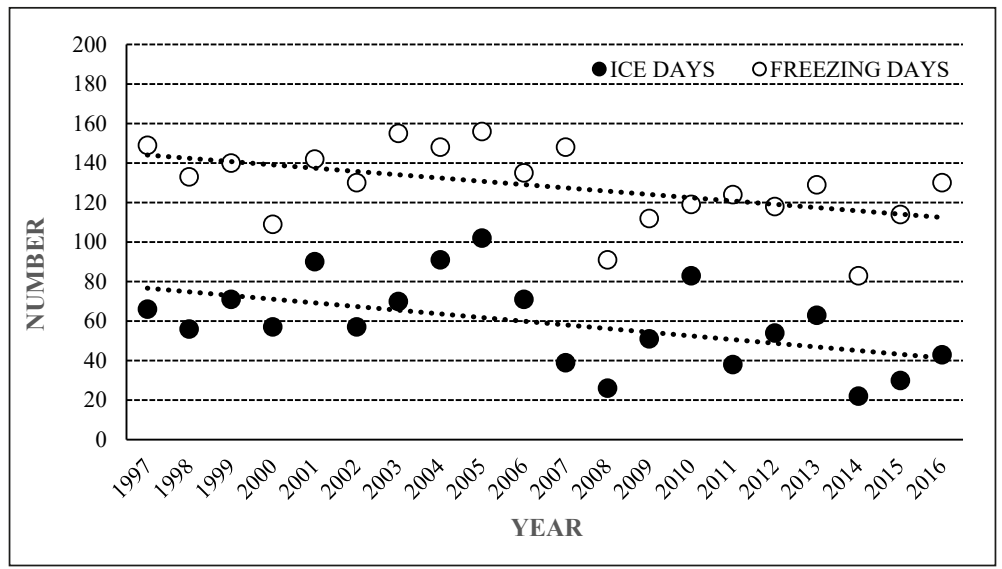

Fig. 5: Number and trend in number of ice and freezing days at the study site of Bíly Kríz (the Beskids Mts.) during 1997-2016.

The occurrence of "hot period" at the beginning (October) and in the end (March) of the cold period is very interesting. Since 1997 the number of "hot periods" has increased at the study site of Bílý Kř́ž mainly in recent years (Fig. 6). Occurrence of these warmer periods can prolong the length of the growth season. Extension of the length of the growth season via earlier onset of spring and later onset of autumn phenological events has been presented by a number of authors (Chen and Xu 2012, Petrie et al. 2015, Thompson and Paul 2017). Consequently, the length of the growth season at middle and high latitudes of European forest has been reported (Crabbe et al. 2016).

\section{Conclusions}

It is evident that temperature conditions have changed at the mountain study site of Bílý Kříž (the Beskids Mts., Czech Republic). Differences can be seen when comparing selected long-term mean air temperature characteristics with mean air temperature characteristics for the 19972016 period (Tab. 2 and 3). The results show slightly increasing air temperature indicated not only by mean annual air temperature values but also by changes in number of extreme days (summer, tropical, ice, etc.) and the occurrence of hot period

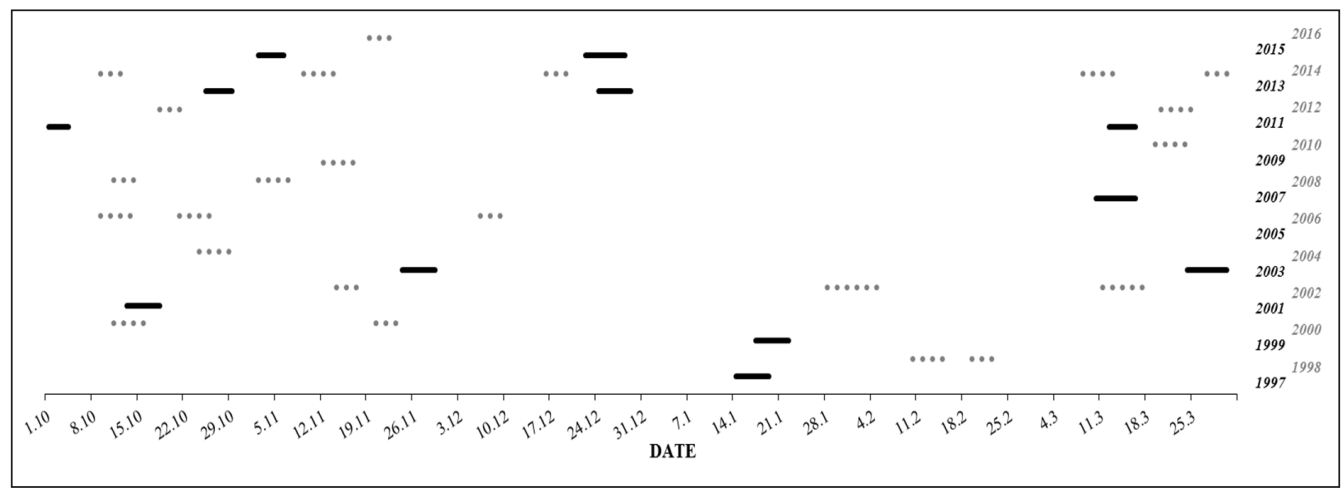

Fig. 6: The occurrence of the "hot periods" at the study site of Bílý Kř́z (the Beskids Mts.) in the cold period (October-March) during 1997-2016. 
Tab. 2: Comparison of mean annual airtemperature at the study site of Bíly Kř́z (the Beskids Mts.) with the longterm values determined for the region.

\begin{tabular}{l|c}
\hline & $\begin{array}{c}\text { Mean annual } \\
\text { air temperature }\left({ }^{\circ} \mathbf{C}\right)\end{array}$ \\
\hline Long-term mean at the study site of Bílý Kř́ž in the period of 1997-2016 & $6.3 \pm 0.9$ \\
Long-term mean in the region in the period of 1961-2000* & $5-6$ \\
Normal value in the region in the period of 1961-1990 & $5-6$ \\
Normal value in the region in the period of $1981-2010^{* * *}$ & $6-7$ \\
\hline
\end{tabular}

* according to Tolasz et al. 2007

** according to http://portal.chmi.cz/historicka-data/pocasi/mapy-charakteristik-klimatu

*** according to http://portal.chmi.cz/historicka-data/pocasi/mapy-charakteristik-klimatu

\begin{tabular}{l|c|c}
\hline & $\begin{array}{c}\text { Long-term mean } \\
\text { at the study site of Bílý Kř́íž } \\
\text { in the period of 1997-2016 }\end{array}$ & $\begin{array}{c}\text { Long-term mean } \\
\text { in the region } \\
\text { in the period of 1961-2000 } \\
\text { according to Tolasz et al. } \\
\text { (2007) }\end{array}$ \\
\hline Maximum air temperature $\left({ }^{\circ} \mathbf{C}\right)$ & $31.9 \pm 2.1$ & $28-29$ \\
Minimum air temperature $\left({ }^{\circ} \mathbf{C}\right)$ & $-17.2 \pm 3.5$ & $(-19)-(-20)$ \\
Length of the growth season (days) & $195 \pm 16$ & $180-200$ \\
Date of the growth season begining & 19.04. & $10.04 .-20.04$. \\
Date of the growth season end & 24.10. & $20.10 .-25.10$. \\
Summer days (number) & 29 & $10-20$ \\
Tropical days (number) & 6 & $0-1$ \\
Tropical nights (number) & 0.7 & $0-0.1$ \\
Ice days (number) & 59 & $60-70$ \\
Freezing days (number) & 128 & $140-160$ \\
\hline
\end{tabular}

\section{Aknowledgement}

This work was supported by the Ministry of Education, Youth and Sports of the Czech Republic within the programme INTER-EXCELENCE (INTER-COST), grant No. LTC17007 and by the Ministry of Education, Youth and Sports of the Czech Republic within the National Sustainability Program I (NPU I), grant number LO1415.

\section{References}

AltMan, J., Fibich, P., ŠantrưČKovÁ, H., Doležal, J., ŠTĚPÁNeK, P., KopÁČeK, J., HunovÁ, I., OULeHLe, F., Tumajer, J., Cienciala, E. 2017: Environmental factors exert strong control over the climate-growth relationships of Picea abies in Central Europe. Science of the Total Environment, 609: 506-516.
Bonan, G.B. 2008: Forests and climate change: forcing, feedbacks, and the climate benefits of forest. Science, 320: 1444-1449.

Carrara, A., Janssens, I.A., Yuste, J.C., CeuleMANS, R. 2004: Seasonal changes in photosynthesis, respiration and NEE of a mixed temperate forest. Agricultural and Forest Meteorology, 126: 15-31.

Chen, J.M., Govind, A., Sonnentag, O., Zhang, Y., BARR, A., Amiro, B. 2006. Leaf area index measurements at Fluxnet-Canada forest sites. Agricultural and Forest Meteorology, 140: 257-268.

Chen, X., Xu, L. 2012: Temperature controls on the spatial pattern of tree phenology in China's temperate zone. Agricultural and Forest Meteorology, 154-155: 195-202.

Crabbe, R.A., Dash, J., Rodriguez-Galiano, V.F., Janous, D., PavelKa, M., MareK, M.V. 2016: EXtreme warm temperatures alter forest phenology and productivity in Europe. Science of the Total Environment, 563-564: 486-495. 
Croitoru, A.-E., Piticar, A., Ciupertea, A.-F., RoşcA, C.F. 2016: Changes in heat waves indices in Romania over the period 1961-2015. Global and Planetary Change, 146: 109-121.

D'Amato, A.W., Bradford, J.B., Fraver, S., Palik, B.J. 2011: Forest management for mitigation and adaptation to climate change: Insights from long-term silviculture experiments. Forest Ecology and Management, 262: 803-816.

DANG, H., UngER, N. 2015: Contrasting regional versus global radiative forcing by megacity pollution emissions. Atmospheric Environment, 119: 322-329.

Elizbarashvili, M., Elizbarashvili, E., Tatishvili, M., Elizbarashvili, S., Meskhia, R., Kutaladze, N., King, L., Keggenhoff, I., Khardziani, T. 2017: Georgian climate change under global warming conditions. Annals of Agrarian Science, 15: 17-25.

Franke, A.K., Bräuning, A., Timonen, M., Rautio, P. 2017: Growth response of Scots pines in polar-alpine tree-line to a warming climate. Forest Ecology and Management, 399: 94-107.

Granier, A., Biron, P., Lemoine, D. 2000: Water balance, transpiration and canopy conductance in two beech stands. Agricultural and Forest Meteorology, 100: 291-308.

Groot, A., SaUcie, J.-P. 2008. Volume increment efficiency of Picea mariana in northern Ontario, Canada. Forest Ecology and Management, 255: 1647-1653.

Guerrero-Meseguer, L., Marín, A., Sanz-LÁZaro, C. 2017: Future heat-waves due to climate change threaten the survival of Posidonia oceanica seedling. Environmenta Pollution, 230: 40-45.

Guлот, J. 2012: A robust spatial recontruction of April to September temperature in Europe: Comparison between the medieval period and the recent warming with a focus on extreme values. Global and Planetary Change, 84-85: 14-22.

Gustafson, E.J., Miranda, B.R., De Bruijn, A.M.G., SturteVAnt, B.R., Kubiske, M.E. 2017: Do rising temperatures always increase forest productivity? Interacting effects of temperature, precipitation, cloudiness and soil texture on tree species growth and competition. Environmental Modelling $\%$ Software, 97: 171-183.

Hadden, D., Grelle, A. 2016: Changing temperature response of respiration turns boreal forest from carbon sink into carbon source. Agricultural and Forest Meteorology, 223: 30-38.
Jaganathan, C., Dash, J., Atkinson, P.M. 2014: Remotely sensed trends in the phenology of northern high latitude terrestrial vegetation, controlling for land cover change and vegetation type. Remote Sensing of Environment, 143: 154-170.

Kulakowski, D., Seidl, R., Holeksa, J., Kuuluvainen, T., Nagel, T.A., Panayotov, M., SvoBoda, M., Thorn, S., Vacchiano, G., Whitlock, C., Wohlgemuth, T., BeBi, P. 2017: A walk on the wild side: Disturbance dynamics and the conservation and management of European mountain forest ecosystems. Forest Ecology and Management, 388: 120-131.

Linder, M., Maroschek, M., Nethere, S., Kremer, A., Barbati, A., Garcia-Gonzalo, J., Seidl, R., Delzon, S., Corona, P., Kolström, M., Lexer, M.J., Marchetti, M. 2010: Climate change impacts, adaptive capacity, and vulnerability of European forest ecosystems. Forest Ecology and Management, 259: 698-709.

Madrigal-González, J., Herrero, A., Ruiz-Benito, P., ZaVALA, M.A. 2017: Resilience to drought in a dry forest: Insights from demographic rates. Forest Ecology and Management, 389: 167-175.

Marková, I., Pavelka, M., TomášKová, I., Janouš, D. 2009: Yearbook of meteorological measurements 2007. Experimental ecological study site Bílý Křž (Moravian-Silesian Beskids Mts.). Ústav systémové biologie a ekologie AV ČR, v. v. i., Brno, $81 \mathrm{pp}$.

Matcharashvili, T., Zhukova, N., Chelidze, T., Founda, D., Gerasopoulos, E. 2017: Analysis of long-term variation of the annual number of warmer and colder days using Mahalanobis distance metrics - A case study for Athens. Physica A: Statistical Mechanics and its Applications, 487: 22-31.

Mekonnen, Z.A., Grant, R.F., Schwalm, Ch. 2016: Contrasting changes in gross primary productivity of different regions of North America as affected by warming in recent decades. Agricultural and Forest Meteorology, 218-219: 50-64.

Mitdrexler, D., Yang, Z., Cohen, W.B., Bell, D.M. 2016: A forest vulnerability index based on drought and high temperatures. Remote Sensing of Environment, 173: 314-325.

Misson, L., Rasse, D.P., Vincke, C., Aubinet, M., FrançoIs, L. 2002: Predicting transpiration from forest stands in Belgium for the $21^{\text {st }}$ century. Agricultural and Forest Meteorology, 111: 265-282. 
Nelson, H.W., Williamson, T.B., Macaulay, C., Mahony, C. 2016: Assessing the potential for forest management practitioner participation in climate change adaptation. Forest Ecology and Management, 360:388-399.

NOAA National Centers for Environmental Information, State of the Climate: Global Analysis for Annual 2016, published online January 2017, retrieved on September 11, 2017 from https://www.ncdc.noaa.gov/sotc/ global/201613.

Petrie, M.D., Pockman, W.T., Pangle, R.E., Limousin, J.M., Plaut, J.A., McDowell, N.G. 2015: Winter climate change promotes an altered spring growing season in pinon pine-juniper woodlands. Agricultural and Forest Meteorology, 214-215: 357-368.

PreinIng, O. 1992: Global warming: greenhouse gases versus aerosols. Science of the Total Environment, 126: 199-204.

Ramanathan, V., Feng, Y. 2009: Air pollution, greenhouse gases and climate change: Global and regional perspectives. Atmospheric Environment, 43: 37-50.

RUSTAD, L.E. 2008: The response of terrestrial ecosystems to global climate change: Towards an integrated approach. Science of the Total Environment, 404: 222-235

Schleip, Ch., Rais, A., Menzel, A. 2009: Bayesian analysis of temperature sensitivity of plant phenology in Germany. Agricultural and Forest Meteorology, 149: 1699-1708.

Thompson, J.A., PaUL, D.J. 2017: Assessing spatial and temporal patterns in land surface phenology for the Australian Alps (2000-2014). Remote Sensing of Environment, 199: 1-13.

Tolasz, R., BRÁzdIL, R., Bulíř, O. et al. 2007: Climate Atlas of the Czechia. Český hydrometeorologický ústav, Univerzita Palackého, Praha, 256 pp.

Vitasse, Y., Delzon, S., Dufrêne, E., Pontailler, J.Y., Louvet, M., Kremer, A., Michalet, R. 2009: Leaf phenology sensitivity to temperature in European trees: Do within-species populations exhibit similar responses? Agricultural and Forest Meteorology, 149: 735-744.

Vitasse. Y., Schneider, L., RiXen, Ch., Christen, D., REBETEZ, M. 2018: Increase in the risk of exposure of forest and fruit trees to spring frosts at higher elevations in Switzerland over the last four decades. Agricultural and Forest Meteorology, 248: 60-69.
Wason, J.W., Bevilacqua, E., DovciaK, M. 2017: Climate on the move: Implications of climate warming for species distributions in mountains of the northeastern United States. Agricultural and Forest Meteorology, 246: 272-280.

Wu, Ch., Gonsamo, A., Chen, J.M. et al. 2012: Interannual and spatial impacts of phenological transitions, growing season length, and spring and autumn temperatures on carbon sequestration: A North America flux data synthesis. Global and Planetary Change, 92-93: 179-190.

Zampieri, M., Russo, S., di Sabatino, S., Micchetti, M., Scoccimarro, E., Gualdi, S. 2016: Global assessment of heat wave magnitudes from 1901 to 2010 and implications for the river discharge of the Alps. Science of the Total Environment, 571: 1330-1339. 